\title{
THE COOPERATIVE PRINCIPLE VIOLATION IN CLASSROOM TEACHING LEARNING PROCESS
}

\author{
David Togi Hutahaean*1, Christian Neni Purba*2 ${ }^{*}$ Herman ${ }^{* 3}$ \\ davidhutahaean138@gmail.com ${ }^{* 1}$, bochubojg2@ gmail.com ${ }^{* 2}$, herman@uhn.ac.id ${ }^{* 3}$ \\ English Education Department ${ }^{* 1,2,3}$, University of HKBP Nommensen, Medan, Indonesia ${ }^{* 1,2,3}$
}

\begin{abstract}
The purpose of this research is to investigate the cooperative principle violation between the teacher and the students in grade eighth classroom teaching and learning process at one Junior High school in Pematangsiantar. The research question was: What cooperative principles are violated by the teacher and the students in grade eighth classroom teaching and learning process. This research was done in classroom research design with one teacher and 30 students in the classroom teaching and learning process. The participants were chosen from one Junior High school in Pematangsiantar. Their conversations during the process of teaching and learning were analyzed through the cooperative principle violation between the teacher and the students in grade eighth classroom teaching and learning process at that school in Pematangsiantar. After analyzing the data, the researchers found that the maxim are flouted if the information is more informative than is required, ambiguous, uses symbolic, not absolutely true, lack of adequate evidence.
\end{abstract}

Keywords: Cooperative principle, maxims, pragmatics, teaching-learning process, violation

DOI: https://doi.org/10.31943/wej.v4i1.74

\section{INTRODUCTION}

Curriculum 2013 that implemented in our country, Indonesia, invites the teacher to make a model of teaching of students-centered where this means that students must be active participants in teaching and learning process. To implement this model of teaching is not as easy as to say. The most common barriers that all teachers, especially in English teacher, are students are usually passive (silent). One of the reasons why this happens is because of English position as foreign language in Indonesia. In order to create a communicate interaction to achieve goals of teaching, teachers should apply a good communication with students. But that's not a simple way since the interaction between teacher and students does not run well because of students' different background. In previous study conducted by Sri Agung (2016) in 
his research entitled "the violation of cooperative principles on students' responses toward teacher questions in TEFL class", he stated the similar problems occurred in teaching and learning process where the students were passive.

To facilitate the problem in a good way, teacher must build a good communication through language. Language as a means of communication is the way of behaving to interact one another to represent their ideas and thought of men's minds to be conveyed from one to another. It will be difficult to express our intention to our listener without language. For example, when a child wanted to have a lunch she/he would have to use signs such a pointing out her/his mount and stomach. She/he would not be able to tell at once what she/he means that she/he was hungry, then there will be misunderstanding.

In short, the most important thing in using language as a mean communication is the message carried, which is called meaning. Language without meaning is useless. Meaning makes little sense except in the context of communication, the nation of communication therefore provides a good a place as any to start an exploration of meaning. Communication can be conceived very broadly, including within it scope such matter the transfer of information between biological generation via the genethic code, the interaction between a driver and his car, and indeed any sort of stimulus response situation (Cruse, 2000:15). Sometimes, speaker doesn't say what she/he means. She/he utters something for different intention, aimed to unhurt the other feeling, or event to offend him/her. For example, Mike and Anny are in living room.

Mike : Do you like to have dinner in the living room or in the kitchen?

Anny : It's cold in here.

What Anny intents is, "let's eat in the kitchen" but she utters another expression with a hope that Mike will understand the meaning or message carried.

When both speaker and listener or hearer don't have a cooperative principle, they will not have meaning of the topic spoken. Otherwise, the cooperative principle helps us to understand and interpret easily what the speaker utters, if only it is obeyed.

It is common for people to break the rule in cooperative principle while they are doing conversation. The action is called violation. When speaker does not obey the principle, it means that she/he is doing "violation of cooperative principle".

For example:

Rudy: Will you accompany me to my uncle's party?

Mary : I have to pick my brother up, then we will go for shopping with my mother.

In the conversation, Rudy actually needs an answer whether Mary will go with him or not. Mary's answer indicates that she/has many things to do at the time and she just catches the surface meaning of Rudy's utterance. Therefore, she doesn't fulfill the need even though she is expected to provide it more. 


\section{Hutahaean $^{* 1}$, Purba ${ }^{* 2}$, and Herman ${ }^{* 3}$ \\ THE COOPERATIVE PRINCIPLE VIOLATION IN CLASSROOM \\ TEACHING LEARNING PROCESS}

Sometimes, in communication people do some strategies in order to make their conversation goes right. They are flouting and hedging maxim. Both of those strategies found in almost of our daily conversation, but occasionally we do not realize it. Theoretically, Grice (1975:45) stated that the people should apply the cooperative principle that is reflected in the four maxims of conversation, they are maxim of quantity, the maxim of quality, the maxim of relevance, and the maxim of manner. Grice (1975:45) who proposed those maxims, said that people should obey those maxims in order to have an effective communication without any miscommunication. In fact, sometimes people deliberately flout and hedge the maxims but it does not lead to miscommunication. Flouting a maxim is a particular silent way of getting an address to draw inference and hence recovers an implicature (Grundy, 2000:78). There are all sorts of reasons to flout of maxims. Sometimes one is faced with clash of maxims and chooses simply to drop one, sometimes one is not in position to say what the maxim requires, or is obliged to say something that the maxim forbids.

According to Cook (1989:31-32) there are meaning derives from deliberate violations. It can be happened in many ways. Quality flout, when communication degenerates into lying, or simply breaks down altogether. Quantity flout, when we say more than we need to mark a sense of occasion or respect, and when we say less than we need, perhaps to be rude or blunt. Relation flout, when communication turns into signal embarrassment or a desire to change the subject. Manner flout, when the information shared makes ambiguity, or it is violated either for humor.

Violations mentioned here was similar to Littlejohn and Foss (2011) statement. They stated that saying something indirectly is an example of the most common types of violation. This statement indicates that when someone used indirectly utterance, they made violated maxim of cooperative principle. When someone did not respond the utterance when speaking to other people, he/she also did the violation. This condition was the same with the experience depicted by the researchers when doing observation in the class at one Junior High school in Pematangsiantar. Some students made the violation since every student had different background, skill, ability and so on. The violation occurred in the opening, middle and the end of teaching and learning process. The violations that done by the students such as responding the teacher's utterance indirectly, no respond at all to the teacher, and so on. In order to achieve the goal of teaching and learning process, cooperative principles during the teaching and learning processes are really needed. In short, he aim of spoken English teaching is to improve students' communicative competence, and Cooperative Principle can have positive effect on spoken English teaching. That's why, it is necessary for the students to master the basic knowledge of Cooperative Principle. As a result, the Cooperative Principle can be applied to the teaching of spoken English. Based on the phenomena mentioned above, the researchers were interested to conduct a research in order to investigate the violations between teacher and students in the teaching and learning process. A meaningful and effective conversation can be created through the 
Wiralodra English Journal (WEJ)

Vol 4 No 1 Maret 2020

cooperative principle which can avoid the misunderstanding and misinterpretation between teacher and students.

\section{LITERATURE REVIEW}

\section{The Meaning of Pragmatics}

According to Levinson (1997) in Pardede, Herman and Pratiwi (2019:2) pragmatics is the study of ability of language users to pair sentences in the context which they would be appropriate. Hence, Green (1996) as quoted by Grundy (2000:214) defined pragmatics as the study of understanding intentional human action. It concerns with the way in which people use language through action. Furthermore, Yule (1996:4) as cited in Herman (2015:41) define pragmatics as the study of relationships between linguistic forms and the users of those forms and pragmatics is the only one allowing human into the analysis because through pragmatics one can talk about people's intended meanings, their assumptions, their purposes, and the kinds of actions such as requests and apologizes when they speak.

There are some features of language use that are important in pragmatics (Grundy, 2000:3-15), they are:

1. Appropriate, it concerns with the appropriateness of an utterance in relation to who use it and they addressee.

2. Non-literal or indirect meaning, sometimes when speaker try to make their utterance being appropriate to the context in which they occurred, many of the utterances seem to be indirect rather than literal meaning since not all the speakers intended them to convey.

3. Inference, this feature suggests that communication is not only merely a matter of a speaker encoding a though in language and sending. It as spoken message through space or as a written message on paper to a receiver who decodes it. However, the receiver must not only decode what is received but also draw an inference as to what is conveyed beyond what is stated.

4. Indeterminacy, once we make an inference of utterance we have to be ready to get consequently, whether our inference is unclear or as linguists say underdetermined. It means that one utterance have one of several possible meaning and the inference which we are drawn determine these possible meanings as the one of the addressee think about what the speaker is intending. Pragmatics is trying to account in systematic ways for our ability to determine what speakers intend even when their utterance are underdetermined.

5. Context, it help us in determining the meaning of an utterance. The relationship between context and language is a central in pragmatics. One thing we have to consider in studying pragmatics is whether the context determines the way we use language or whether the way we use language determines the context.

6. Relevance, in relevance as the most important principle in accounting for the way we understand language. Since we take every utterance as relevant, we understand utterance in whatever way will make them as relevant as possible. 


\section{Hutahaean $^{* 1}$, Purba $^{* 2}$, and Herman ${ }^{* 3}$}

THE COOPERATIVE PRINCIPLE VIOLATION IN CLASSROOM

TEACHING LEARNING PROCESS

7. Reflexivity, it is one part of what we say provides some sort of comment on how our utterance fits into the discourse as a whole or how the speaker want to understood.

8. Misfires, it is important because they tell us that there are expected norms for talk by showing us the effect of not achieving the norm.

Based on the definitions above, the researchers conclude that pragmatics has a strong relation about intended meanings that need listeners to pay more attention in understanding what contexts are.

\section{Implicature}

Implicature is something that is intended is more than what is said. It is caused in communication, the speaker tries to cooperative and the speaker also intends to communicate something with the listener. Thus, implicature correlates with cooperative principle by Paul Grice theory. Yule (1996:35) states that implicature can be considered as an additional conveyed meaning. The notion of implicature can be defined as a new way of describing meaning. Grice's main contribution to the theory of meaning was his original, non-conventional way of treating meaning in conversation, non-natural meaning. Grundy (2000:97) states the contribution of notion of implicature is that it provides some explicit account of how it is possible to mean in some general sense more than what is actually said ( more than what is literally expressed by the conventional sense of linguistic expression uttered). Yule (1996:36) also adds that implicature is a primary example of more being communicated than is said but in order for them to be interpreted, some basic cooperative principle must first be assumed to be in operation.

In pragmatics there are two types of implicature, they are conversational implicature and conventional implicature. Grice says that conversational implicature can be defined as "a different (opposite, additional, etc) pragmatic meaning of an utterance with respect to the literal meaning expressed by utterance" (Mey, 1998:371).Conversational implicature is to be relatedto cooperative principle. On the other hand, according to Grice conventional implicature is determined by the conventional meaning of the words used. Besides, that is not so much based on cooperative principle or that is not dependent on particular context for their interpretation.

\section{Cooperative Principle}

In social science generally and linguistics specifically, the cooperative principle describe how people interact with one another. According to Grice in Nadar (2013:24), stated that "Make your contribution such as it is required, at the stage at which it occurs, by the accepted purpose or direction of the talk exchange in which you engaged". Though phrased as a prescriptive command, the principle is intended as a description of how people normally behave in conversation. 
Listeners and speakers must speak cooperatively and mutually accept one another to be understood in a particular way. The cooperative principle describe how effective communication in conversation is achieved in common social situations. The purpose of conversation is both speaker(s) and listener(s) can achieve the same meaning of the utterances then they can avoid such ambiguity. Listener(s) use the cooperative principle to grasp what the speaker(s) intent and s/he should be able to provide information as complete as she/he needs.

Without cooperative principle, people communication will be far more difficult because the cooperative principle itself is studied in pragmatics will reduce the bewilderment of listener. It will make both speaker and listener's conversational discourse meaningful since they obey the certain principle in the conversation. People who obey the cooperative principle in their language use will make sure that what they say in a conversation furthers the purpose of that conversation. Obviously, the requirements of different types of conversation will be different.

Compare these two following example:

a) A : Did you see my drawing book?

$\mathrm{B}:$ There is a little girl entered the room this afternoon.

b) A : Did you see my drawing book?

B : I've got cat to catch.

In conversation (a), B's answer can help A find the answer of his own question even though B doesn't know the right answer, because the implicature to B's answer is that there is a possibility for the little girl who entered the room to take drawing book. While in conversation (b), there is no relevance between speaker and listener since they are not cooperative each other.

The problem that finally the participant fail to arrive at the same interpretation is their disability to cooperative one with another. According to Grice (1975) there is a general cooperative principle between speakers and hearers which controls or guides the way they speak.

\section{A. Maxim of Quantity (be brief)}

Grundy (2000:74) states that maxim of quantity as one of the cooperative principles is concerned in giving the information as it is required and is not giving the information more than it is required. Therefore, each participant's contribution to conversation should be just as informative as it requires, it should not be less informative or more informative. And say as much as helpful but not more informative or less informative. In a normal circumstance, the maxim of quantity provides that the speaker say just enough, that they do not supply less information or more that is necessary.

$>$ Make your contribution as informative as is required (for the current purposes of exchange).

$>$ Do not make your contribution more informative than is required. 
For examples:

a) A: Where is the hospital?

$\mathrm{B}$ : In the next of that store.

It can be seen that $\mathrm{B}$ information is informative and give enough contribution toward A's question about the exact location of hospital.

b) Mother : what do you need for your examination tomorrow?

Sisca : Pen and dictionary.

Mother : Anything else?

Sisca : No. it's enough.

From the example above, it is clear that sisca is able to give the information as informative as required about her preparation in examination.

c) Peter : Where is Toba lake?

Tiur : North Sumatera.

From the context, what Tiur said is informative because they where in geography class but it won't be informative if they were in North Sumatera or Samosir since peter needs the information specific.

\section{B. Maxim of Quality (be true)}

Grundy (2000:74) stated that maxim of quality can be defined as truthful as required. That means the speaker should inform the truth and they are not allowed to say what they think false and give the statement that run short of proof. Here speaker write are expected to say only what they believe to be true and to have evidence for what they say. However, the speaker must aware of this expression, that the hearers expect them to honor the maxim of quality. According to Cruse (2000), this maxim demands a speaker not to make unsupported statements. The Maxim of Quality requires that you:

1. Do not say what you believe to be false.

2. Do not say that for which you lack adequate evidence.

For examples:

a) A : Where is Eiffel tower located?

B : In Paris

Here, Smith gives the correct answer which shows about the true fact.

b) Pungguk : What it the weather like in sahara dessert area? Kayang : It is hot.

Even though Pungguk has never been to Sahara dessert but his information is believed to be true because everybody knows that Sahara dessert has a high temperature. 
c) Teacher : What is the capital city of Indonesia?

Student : Bandung.

The example above shows us that student cannot give an informative answer because everybody knows that the capital city of Indonesia is Jakarta not Bandung. He said something lack of evidence.

\section{Maxim of Relevance (be relevant)}

Maxim of relation or maxim of relevance means the utterance must be relevant with the topic that being discussed. Cutting (2002:35) states that speakers are expected to give information about something that is relevant to what has been said before. Furthermore, Grundy (2000:74) states that maxim of relevance is fulfilled when the speaker give information that is relevant to the topic proceeding. Therefore, each of the speaker or hearer must be relevant to the topic of conversation.

$>$ Be relevant

$>$ Stay on the topic

For examples:

a) Tina : Would you like to tell me the job your description of secretary?

Dini : Well, it is my birthday today.

The conversation above can make the other laugh since it has no relation at all between Tina and Dini.

b) Siti : What is your favorite food? Joko : Fried chicken.

The example above is relevant between speaker and listener since Joko's answer is the kind of food. The point of the relation maxim is the contribution must be informative which is indicated by the relevance of information.

\section{Maxim of Manner (be clear)}

Maxim of manner obligates speaker's utterance to be perspicuous which is not to be ambiguous, obscure, or disorderly and unnecessary prolixity. Therefore, each participants contribution should be reasonably direct, that is, it should not be vague, ambiguous or excessive wordy. Explained by Cutting (2002:35), maxim of manner is when the speakers put information briefly and orderly, the speaker must avoid the obscure and ambiguous information from the hearer. Therefore, each participant must give the information directly and reasonably, and it should not be vague, ambiguous or excessive. This maxim is related to the form of speech we use. Speaker should not to use the words they know but the listeners do not understand or say things. They speaker also should not state something in a long drawn out way if they could say it in a simple manner. The requirement of Manner Maxim

$>$ Avoid obscurity of expression 


\section{Hutahaean $^{* 1}$, Purba $^{* 2}$, and Herman ${ }^{* 3}$}

THE COOPERATIVE PRINCIPLE VIOLATION IN CLASSROOM

TEACHING LEARNING PROCESS

You should not use words you know, but is unfamiliar with listeners. They would not understand.

$>$ Avoid ambiguity

Try to make your words have just one meaning, depends on the context.

$>$ Be brief (avoid unnecessary prolixity)

You should not state something in a long, drawn-out way if you could say it in a much simpler manner.

$>$ Be orderly ( following the natural order or event)

For example:

a) A : What did you think of that drama?

B : I really like of the action of each player. They can play their role as good as possible.

The answer of $\mathrm{B}$ is categorized as maxim of manner, he can answer the question from his partner about the drama clearly. From the explanation mentioned above, We can conclude that although it is very difficult to obey and use all of the cooperative principles and its maxims in uttering or writing the sentences, but it is essential to follow the cooperative principle in order communication run more effectively.

a) A wife asks her husband something to eat for their children

Mother : let's get our children something

Father : well, but not ice cream.

By saying but not ice cream, it shows that it is not wanted to eat and the father wants to make it clear and tries to be straightforward.

b) Lear : Now, tell me whose sword is this and where did you take it?

Edgar : I don't know whose sword it is. I got it from the werehouse.

From the conversation, Edgar followed the rule. He answers the question clearly.

\section{Violation of Cooperative Principle}

A successful conversation, namely the mutual goal will be achieved when the rule of cooperative principle is obeyed. In contrary, if it is not obeyed, both speaker(s) and listener(s) will not get the intention one another. By applying cooperative principle speaker allows the hearer to draw assumption about the speaker's intentions and the implied meaning. The violation intended here is the violation to the certain rules or principles carried to out by the participants of a conversation. Grice as cited in Cutting (2002 :40) says that when the speaker does not fulfill or disobey the maxim, the speaker is said violate them. Violation is the condition where the speakers do not purposefully fulfill certain maxim. When the speakers do the maxim violation, the conversation can be unsuccessful since they will misunderstand each other. The speakers who violate a maxim cause the hearer not to know the truth and only 
understand the surface meaning. The principle that is violated is cooperative principle that is divided into four sub-principle called maxims. So, there are violations to the maxim of quantity, maxim of quality, maxim of relevant, maxim of manner.

\section{RESEARCH METHOD}

\section{Research Design}

In this research, the researchers used a classroom research. Classroom research was chosen because of the data were in the classroom where the researchers took the data through teaching and learning process between teacher and students. This research design also covered the recording and field note to the data. The data taken in this research were naturally. It means that the recording process was done without the students' awareness in order to make the data more natural. .

\section{Participants}

The participants in this research were one the teacher and 30 students in grade eight classroom teaching and learning process in one school of Junior High School in the city of Pematangsiantar. The data were focused in the conversations during the teaching and learning process, then the conversations were analyzed in order to investigate the cooperative principle violation from the teacher and the students in grade eight classroom teaching and learning process in that school.

\section{Instrument of the Research}

The instrument of this research is voice recorder. The researchers collect the data by recording student's conversation. So the data of this research are student's conversation based on aspects of pragmatics.

\section{The Technique of Data Collection}

The main source of the data in this study was the conversation in teaching and learning process between the teacher and the students in grade eight. The techniques of collecting data were done as follow:

1. Setting the instrument used to take the data in the classroom

2. Starting the teaching and learning process

3 . Recording the conversation between the teacher and the students.

4. Transcribing the conversation from the spoken data into written data.

\section{The Technique of Data Analysis}

To analyze the data, there are some procedures or steps done by the researchers as follow:

1. Underlining the conversation or utterances that violate the maxim.

2. Determining the types of maxim are violated in conversation or utterances based on Grice's theory (1975).

3. Counting the violated for each maxim by using the percentage formulas 


\section{$\mathrm{X}=\frac{\mathrm{F}}{\mathrm{N}} \times 100 \%$}

Note: $\quad \mathrm{X}=$ the percentage of the violation for each maxim

$\mathrm{F}=$ frequency

$\mathrm{N}=$ total number of violations

4. Finding the dominant violated maxims

\section{FINDING AND DISCUSSION}

Based on the data analysis, the researchers provided some findings for every point such as:

\section{Maxim of Quantity}

Grade VIII students in one of Junior High in Pematangsiantar violate the maxim of quantity through some data such as:

Data 1: Nggak miss

Data $2:$ Nggak tau miss,

Oh...

Data $6:$ Oh...

Data 8 : Kasihan kawan- kawan itu?,

Woi kapur mana?

Data 9 : Woi, suaranya disisni miss ini

Data 10 : Ikutlah untuk bicara

For the cooperative principle, grade VIII students violated the maxim of quantity. From the data above, it is shown that the students contributed more than the required. As stated in the theory that in conversation the participants should make their contribution as informative as is required (for current purposes of exchange) and don't make your contribution more informative than is required.

\section{Maxim of Quality}

Grade VIII students in one of Junior High in Pematangsiantar violate the maxim of quality through some data such as:

Data $1: \underline{\text { Hahahaha... Dion miss, }}$

Nggak bawa miss

Data $8:$ Siapa yang bilang itu?

Data 10 : Bonus apa itu?

Data above states that the maxim of quality of cooperative principles showed that don't say what you believe to be false and don't say that for which you lack adequate evidence. 
Wiralodra English Journal (WEJ)

Vol 4 No 1 Maret 2020

\section{Maxim of Relevant}

Grade VIII students in one of Junior High in Pematangsiantar violate the maxim of relevant through some data such as:

Data 1: Eiths...,

Sejenis makanan ringan,

Data 2: Nggak tau miss,

Membaca,

Data 4: Meow..

Agah,

Data 5: $\underline{\text { Meow. }}$.

Kadal,

Data 8: Nggak mau, makanya beli,

Cie...cie....

Data 9: Enaklah,

Yang ributan kau, Kau juga,

$\underline{\text { Sngon dia do on, Aha do roa on, }}$

Based on the finding of the data analysis above, grade VIII students of SMP in Pematangsiantar violate the maxim of relevant which it meant that the utterance must be relevant with the topic.

\section{Maxim of Manner}

Grade VIII students in one of Junior High in Pematangsiantar violate the maxim of manner through some data such as

Data 1: Teka-teki silang,

Dari atas ke bawah, dari kiri ke kanan, dari samping

Data 2: Terjemah kata- kata

Data 3: Cepat kali

Data 4: Walaupun dari kampong- kampong nak

Data 5: Bukan kadal tapi kadel,

Data 7: Makanya jagan cuman ribut kerjanya

Violation done in the maxim of manner of the cooperative principles was that the avoid obscurity of expression, avoid ambiguity, be brief (avoid unnecessary prolixity), be orderly (avoid natural order or event).

The percentage type of maxim violation done by teacher ad students in teaching learning process in one school of Junior High in Pematangsiantar can be seen in the following table 4.1 


\subsection{The percentage type of maxims violated}

\begin{tabular}{|c|c|c|c|}
\hline No & Maxims violated & Frequency & Percentage \% \\
\hline 1 & Quantity & 8 & $25 \%$ \\
\hline 2 & Quality & 4 & $12,5 \%$ \\
\hline 3 & Relevant & 13 & $40,625 \%$ \\
\hline 4 & Manner & 7 & $21,875 \%$ \\
\hline & Total & $\mathbf{3 2}$ & $\mathbf{1 0 0 \%}$ \\
\hline
\end{tabular}

From the table, it was found that the violated of maxim of quantity $8(25 \%)$, the violated of maxim of quality $4(12,5 \%)$, the violated of relevant $13(40,625 \%)$, the violated of maxim of manner $7(21,875 \%)$. The frequency and percentage shows that maxim of relevant is the dominant type of maxim which is violated. Hence, the researchers also discuss that mostly the maxim found in eighth classroom teaching and learning process in SMP N 11 Pematangsiantar is maxim of Relevant. We can see the result of the research finding in the previous page. All of the data analysis contained maxim of relevance are 13 maxim that be relevant in saying and related to the question answer, maxim of quality are 4 maxim that's don't say what you believe to be false and don't say that for which you lack adequate evidence, don't know whether his sentence is true or false. Maxim of manner are 7 maxim that's be brief and orderly ovoid ambiguity and obscurity of expression. Maxim of quantity 8 maxim that's make your contribution as informative as is required and don't make your contribution more informative than is required.

After conducting the data analysis by using the theory of Grice (1975), Yule (1996) and Cutting (2002), the researchers would like to discuss that the cooperative principle violation in teaching learning process in the classroom covered all maxims were violated, they were quantity, quality, relevant and manner. Based on the findings in this research, the researchers inferred that there was a similarity with the findings of the research done by Sri Agung (2016) in his research entitled The violation of cooperative principles on students' responses toward teacher questions in TEFL class. The theory used was the same by Yule's theory (1996), it was about violation of maxims. The difference of the research done by Sri Agung with this research was on the theory that Sri Agung use was only Yule (1996) meanwhile this research used the combination theory from Grice, Yule and Cutting. The participants in this research were students at grade eight, while Sri Agung's was students in TEFL class, university. The finding in Sri Agung's research was there were three types of maxim that were violated on students maxim of quantity, maxim of quality and maxim of manner. Then, maxim of quantity was mostly violated on students' responses. In this research, all maxims were violated and the most violated one was maxim of relevant. The differences happened between this research with the previous (Sri Agung) might be focused on the participants. Students' personality, self 
Wiralodra English Journal (WEJ)

Vol 4 No 1 Maret 2020

confidence, maturity and also age played an important role in the data taken and also the finding from the data analysis.

\section{CONCLUSION}

Based on the finding that is explained, it can be concluded that there are four types cooperative principle are violated by the teacher and the students in grade eighth classroom teaching and learning process in one of Junior High in Pematangsiantar. There are maxim of quantity $8(25 \%)$, the maxim of quality $4(12,5 \%)$, the maxim of relevant $13(40,625 \%)$, the maxim of manner $7(21,875 \%)$. The finding shows that from cooperative principle point of view, most of the classroom teaching learning process in one SMP located in Pematangsiantar is induced by the speaker's habit in telling something without giving enough information or event providing it too much by adding something unimportant to say which is aimed at giving much lesson for the reader. Last but not least, the research would like to recommend the teacher, especially English teacher in comprehending the maxims which cover cooperative principle in order to achieve the goal in teaching and learning process to the students. English lecturers are suggested to use communicative language in delivering questions. As the result, the students are able to answer clearly and briefly as much informative as required on teacher questions. The researchers hope that case like ever happened in campus in Medan where one student killed his/her lecturer will not happen again because of a bad communication. A good communication supports the goal in teaching process and also for the relation between teacher and students. The students also need to be given an understanding related to the maxims in order to have a good communication, not only to teachers, but also to other students, friends, and society.

\section{REFERENCES}

Cook, G. (1989). Pragmatics. New York: Oxford University Press

Cutting, J. (2002). Pragmatics and Discourse: A Resource Book for Students. New York: Routledge

Cruse, D. A. (2000). Meaning in Language. New York: Oxford University Press

Grice, H. P. (1975). Logic and Conversation. Cambridge : Cambridge University Press

Grundy, P. (2000). Doing Pragmatics. London: Oxford University Press 
Herman. (2015). Illocutionary acts analysis of Chinese in Pematangsiantar. International Journal of Humanities and Social Science Invention. ANED. 29.7722/0401202041048.

Available at: http://www.ijhssi.org/papers/v4(12)/Version2/E0401202041048.pdf

Hutajulu, F. S. L. and Herman (2019). Analysis of Illocutionary Act in the Movie "You Are My Home" English Subtitle. Journal of English Educational Study. Volume 2 Issue 1 May 2019 Page 29-36. E-ISSN: 2655-0776. Available at: http://jurnal.stkippersada.ac.id/jurnal/index.php/JEES/article/view/371

Moleong, L. J. (2007). Qualitative Research : New York. Oxford University Press

Mey. J. C. (1998). Pragmatics: An Introduction. Oxford: Blackwell

Nadar, F.X. (2013). Pragmatik \& Penelitian Pragmatik. Yogyakarta: Graha Ilmu

Paltridge, B. (2000). Making Sense of Discourse Analysis. Queensland: Antipodean Educational Enterprises

Pardede, H., Herman, and Pratiwi, W. (2019). An Analysis of Politeness Principle Maxims Found in Big Hero 6 Movie. European Exploratory Scientific Journal. Vol. 3,4 No. Available at: https://syniutajournals.com/index.php/EESJ/article/view/87/80

Sobhani, A. and Saghebi, A. (2014). The Violation of Cooperative Principles and Four Maxims in Iranian Psychological Consultation. Open Journal of Modern Linguistics, Vol.4 No.1(2014), Article ID:42896,9 pages DOI:10.4236/ojml.2014.41009

Sri Agung, W.K. (2016). The violation of cooperative principles on students' responses toward teacher questions in TEFL class. Kodifikasia, Volume 10 No. 1 Tahun 2016

Yule, George. (1996). Pragmatics. London: Oxford University Press

Zebua, E., Rukmini, D., and Saleh, M. (2017). The Violation and Flouting of Cooperative Principles in the Ellen Degeneres Talk Show. LANGUAGE CIRCLE:Journal lof Language and Literature 12(1) October 2017. Available online at http://journal.unnes.ac.id 